\title{
Article
}

\section{The Abscopal Effect in the Era of Checkpoint Inhibitors}

\author{
Ondřej Kodet ${ }^{1,2,3, * \mathbb{D}}$, Kristýna Němejcova ${ }^{4}\left(\mathbb{D}\right.$, Karolína Strnadová ${ }^{2} \mathbb{D}$, Andrea Havlínová ${ }^{1}$, Pavel Dundr ${ }^{4}$, \\ Ivana Krajsová ${ }^{1}$, Jiří Štork ${ }^{1}$, Karel Smetana, Jr. ${ }^{2,3}$ DD and Lukáš Lacina ${ }^{1,2,3, *(D)}$ \\ 1 Department of Dermatovenereology, First Faculty of Medicine and General University Hospital, Charles \\ University, 12800 Prague, Czech Republic; andrea.havlinova@vfn.cz (A.H.); ivana.krajsova@vfn.cz (I.K.); \\ jiri.stork@lf1.cuni.cz (J.Š.) \\ 2 Institute of Anatomy, First Faculty of Medicine, Charles University, 12800 Prague, Czech Republic; \\ karolina.strnadova5@gmail.com (K.S.); karel.smetana@lf1.cuni.cz (K.S.J.) \\ 3 Biotechnology and Biomedicine Center, Academy of Science and Charles University, \\ 25250 Vestec, Czech Republic \\ 4 Institute of Pathology, First Faculty of Medicine and General University Hospital, Charles University, \\ 12800 Prague, Czech Republic; Kristyna.Nemejcova@vfn.cz (K.N.); pavel.dundr@vfn.cz (P.D.) \\ * Correspondence: ondrej.kodet@lf1.cuni.cz (O.K); lukas.lacina@lf1.cuni.cz (L.L.)
}

check for updates

Citation: Kodet, O.; Němejcova, K.; Strnadová, K.; Havlínová, A.; Dundr, P.; Krajsová, I.; Štork, J.; Smetana, K., Jr.; Lacina, L. The Abscopal Effect in the Era of Checkpoint Inhibitors. Int. J. Mol. Sci. 2021, 22, 7204. https:// doi.org/10.3390/ijms22137204

Academic Editor: Beate Heissig

Received: 18 May 2021

Accepted: 1 July 2021

Published: 4 July 2021

Publisher's Note: MDPI stays neutral with regard to jurisdictional claims in published maps and institutional affiliations.

Copyright: (c) 2021 by the authors. Licensee MDPI, Basel, Switzerland. This article is an open access article distributed under the terms and conditions of the Creative Commons Attribution (CC BY) license (https:/ / creativecommons.org/licenses/by/ $4.0 /)$.

\begin{abstract}
Therapy targeting immune checkpoints represents an integral part of the treatment for patients suffering from advanced melanoma. However, the mechanisms of resistance are responsible for a lower therapeutic outcome than expected. Concerning melanoma, insufficient stimulation of the immune system by tumour neoantigens is a likely explanation. As shown previously, radiotherapy is a known option for increasing the production of tumour neoantigens and their release into the microenvironment. Consequently, neoantigens could be recognized by antigen presenting cells (APCs) and subjected to effector T lymphocytes. Enhancing the immune reaction can trigger the therapeutic response also at distant metastases, a phenomenon known as an abscopal effect (from "ab scopus", that is, away from the target). To illustrate this, we present the case of a 78-year old male treated by anti-CTLA-4/ipilimumab for metastatic melanoma. The patient received the standard four doses of ipilimumab administered every three weeks. However, the control CT scans detected disease progression in the form of axillary lymph nodes metastasis and liver metastasis two months after ipilimumab. At this stage, palliative cryotherapy of the skin metastases was initiated to alleviate the tumour burden. Surprisingly, the effect of cryotherapy was also observed in untreated metastases and deep subcutaneous metastases on the back. Moreover, we observed the disease remission of axillary lymph nodes and liver metastasis two months after the cryotherapy. The rarity of the abscopal effect suggests that even primed anti-tumour $\mathrm{CD}^{+} \mathrm{T}$ cells cannot overcome the tumour microenvironment's suppressive effect and execute immune clearance. However, the biological mechanism underlying this phenomenon is yet to be elucidated. The elicitation of a systemic response by cryotherapy with documented abscopal effect was rarely reported, although the immune response induction is presumably similar to a radiotherapy-induced one. The report is a combination case study and review of the abscopal effect in melanoma treated with checkpoint inhibitors.
\end{abstract}

Keywords: abscopal effect; cryotherapy; anti-CTLA-4; melanoma; tumor neoantigens; wound healing

\section{Introduction}

Immune checkpoint inhibitors represent a milestone in the immunotherapy of cancer, including melanoma. The monoclonal antibody targeting CTLA-4 (ipilimumab) was the pioneer checkpoint inhibitor on the market, achieving a significant improvement in overall survival (OS) in metastatic melanoma patients. Despite this success, the therapeutic response observed in patients treated by ipilimumab is only about $10 \%$ [1]. However, the most commonly used checkpoint inhibitors nowadays, anti-PD-1 (nivolumab, pembrolizumab), have a significantly higher response (up to $45 \%$ ). The best response was observed with 
combination therapy of anti-CTLA-4 and anti-PD-1 (ipilimumab, nivolumab, as high as $58 \%$ objective response rate, ORR). Not surprisingly, this combination therapy is associated with higher serious side effects of the grades 3 and 4 [2]. Despite these advances in the treatment of metastatic melanoma, many patients do not benefit from immunotherapy.

The mechanisms of resistance to immunotherapy in melanoma are numerous and reflect the complexity of tumour cell interactions with the immune system. Not all of these interactions are fully documented and understood. The principal mechanisms of immunotherapy resistance include:

a. insufficient production and release of neoantigens by the tumour (presumably due to a low mutation load) with consequent insufficient stimulation of immune cells by these neoantigens $[3,4]$;

b. insufficient tumour infiltration by tumour infiltrating lymphocytes (TILs) resulting in immunologically "cold" or "deserted" tumours [5];

c. absence of PD-1-expressing T cells and only transient infiltration of PD-L1-expressing tumour-associated macrophages (TAMs) in metastasis, which might be documented in biopsies at the beginning of therapy [6];

d. presence of an innate transcriptional "signature" of anti-PD-1 resistance (IPRES, innate PD-1 RESistance) [7];

e. insufficient signalling of interferon $\gamma$ [7-11].

Low stimulation of the immune system by tumour-specific neoantigens is indeed one of the critical factors responsible for immunotherapy resistance [12]. The entire concept of the immune system function is based on precise discrimination and response to antigenic stimuli. The immune system can either recognize and tolerate, or destroy if necessary. Tlymphocytes sensitively and specifically differentiate tumour cells from the cells of healthy tissues and thus execute efficient immune surveillance. Melanoma is one of the tumours with the highest mutation burden in humans [13]. This should theoretically increase the possibility of eliciting an immune response [12]. Sadly, some tumours (including melanoma) do not sufficiently produce neoantigens or do not adequately present these neoantigens to the immune system and, hence, cannot be recognized as foreign [14].

The abscopal effect is based on these principles of immune system surveillance [15]. The abscopal effect has been hypothesized as a concept in metastatic cancer treatment since the 1950s. The term "abscopal" (from Latin, "ab"—away from, "scopus"—-target) was used first (in 1953) to describe the observed therapeutic effect of ionizing radiation in the anatomic site, which was not irradiated [16]. In later years, the abscopal effect was observed repeatedly after radiotherapy. In this context, the tumour area (e.g., regional lymph nodes basin) was irradiated. This treatment was followed by surprising regression of metastasis also in distant non-irradiated regions. Since the earliest observations of this phenomenon, it was hypothesized that local radiation triggered a systemic immune response [17-19]. The abscopal effect has been reported in several malignancies, including malignant melanoma or non-small cell lung cancer [17].

The abscopal effect has also been observed after various other types of local treatments such as electroporation or intra-tumoral injection of therapeutics [20,21]. However, the abscopal effect associated with cryotherapy was only scarcely described, and the available data are limited [22].

Mechanistically, the disintegration of tumour cells due to local treatment can release tumour neoantigens. This prerequisite could consequently result in the stimulation of the immune system. Recognition of the tumour-specific neoantigens, their intake and presentation are mediated by dendritic cells (DCs).

These antigen-presenting cells play a crucial role in the initiation and regulation of the innate and adaptive immunity. DCs induce a specific anti-tumour immune response after processing tumour-specific neoantigens $[14,23]$. The antigens are then presented to CD8 ${ }^{+} \mathrm{T}$ cells by MHC molecules class I and to $\mathrm{CD}^{+} \mathrm{T}$ cells by MHC molecules class II. Antigen presentation efficiently performed by mature DCs also contributes to the cytotoxic immune response by activating NK cells [24,25]. 
The abscopal effect was also studied in mouse models where localized radiation was used. In the mouse melanoma model, $\mathrm{CD}^{+} \mathrm{T}$ cells were required to reduce melanoma burden following radiotherapy, and immunotherapy enhanced the response [26]. The abscopal effect has also been observed in wild-type mice treated with a combination of radiotherapy and Flt3-L, a growth factor that stimulates the production of DCs [27]. This study supported the importance of DCs in the induction of the anti-tumour immune response.

Most recently, the abscopal effect attracted the attention of researchers due to the possibilities of combining checkpoint inhibitors and radiotherapy. In a clinical study (MASTERKEY 256) using a combination of radiotherapy and ipilimumab, the abscopal effect was also observed. Later, it was also observed with the combination of talimogene laherparepvec (T-VEC) oncolytic virus vaccine and pembrolizumab [28].

The intratumoral administration of therapeutic viral particles leads to oncolysis; however, it also attracts immune cells to the treated metastatic lesion with an increase of $\mathrm{CD}^{+} \mathrm{T}$ cell infiltration in the tumour stroma [29]. Furthermore, reactive expression of PD-L1 in the tumour microenvironment promotes concomitant blockade of PD-1. After combined therapy, tumour antigen-specific $\mathrm{CD} 8^{+} \mathrm{T}$ cells that were fully stimulated in the injected lesion can traffic and infiltrate distant metastatic lesions to exert systemic anti-tumour activity, thereby reversing primary resistance to PD-1 blockade therapy [28].

We aimed to review the abscopal effect (Figure 1) and its immunological and molecular mechanisms in the context of current immune checkpoint inhibitor therapy. In this light, we demonstrate clinically the abscopal effect observed at our department in a melanoma patient. 


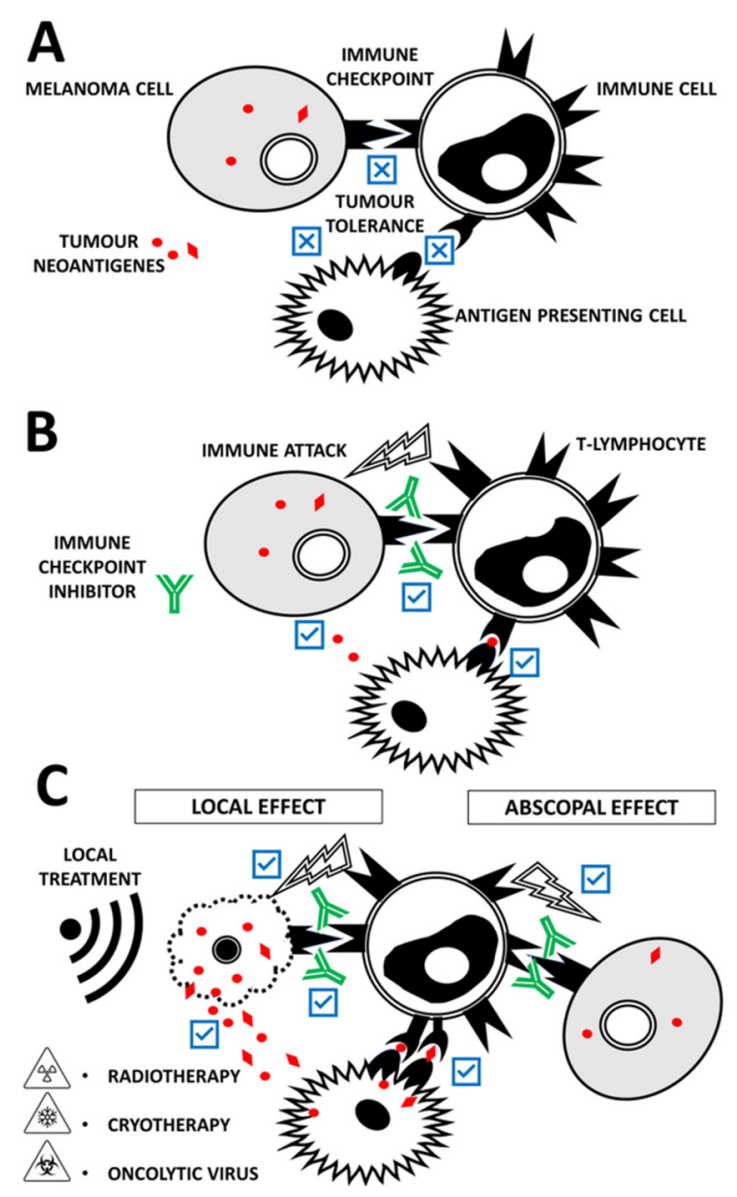

Figure 1. (A) Insufficient production and release of neoantigens by the melanoma cells lead to insufficient stimulation of effector immune cells (if present) by antigen-presenting cells. Tumour cells also express negative regulators of T-cell function. The most prominent druggable checkpoint molecules are CTLA-4 and PD-1/PD-L1 (not differentiated); all of them have been associated with immune evasion in cancer. Thus, tumour tolerance can be established. These mechanisms allow cancer cells to avoid destruction by the immune attack. (B) Administration of immune checkpoint inhibitors such as anti-CTLA4, anti-PD1 and anti-PD-L1 has remarkable success in enhancing the effector anti-tumour response and triggering the immune attack. However, not all patients respond completely to checkpoint inhibitors. Also, tumour cells can gradually develop mechanisms to avoid immune attack. (C) Checkpoint inhibitor therapeutical outcome can be improved in combination with radiotherapy, cryotherapy or oncolytic viruses. All these treatment modalities act locally. Tumour cell damage increases the availability of tumour neoantigens for antigen-presenting cells and effector immune cells. However, immune system activation and thus a therapeutic effect can be observed in the anatomic site, which was not affected by local treatment. This is known as the abscopal effect.

\section{Case Report}

\subsection{Patient}

A 78-year old Caucasian male suffering from metastatic melanoma was referred to our centre for treatment. Primary cutaneous melanoma (Breslow $1.5 \mathrm{~mm}$, without ulceration, BRAFwt) was widely excised from the patient's dorsal skin in 2009. Six years later, we detected disease progression with numerous cutaneous and subcutaneous metastases at the original scar on back in 2015. The patient received standard ipilimumab (anti-CTLA4) treatment (four doses, $3 \mathrm{mg} / \mathrm{kg}$, every three weeks). Unfortunately, further disease progression was confirmed on a CT scan with new axillary lymph nodes metastasis and liver metastasis two months after the last ipilimumab dose administration (Figure 2). The cutaneous metastases were also notably progressing (Figure 3). Therefore, we initiated at 
this time palliative cryotherapy of accessible cutaneous metastases to reduce the tumour burden and alleviated discomfort associated with lesion oozing and haemorrhage.
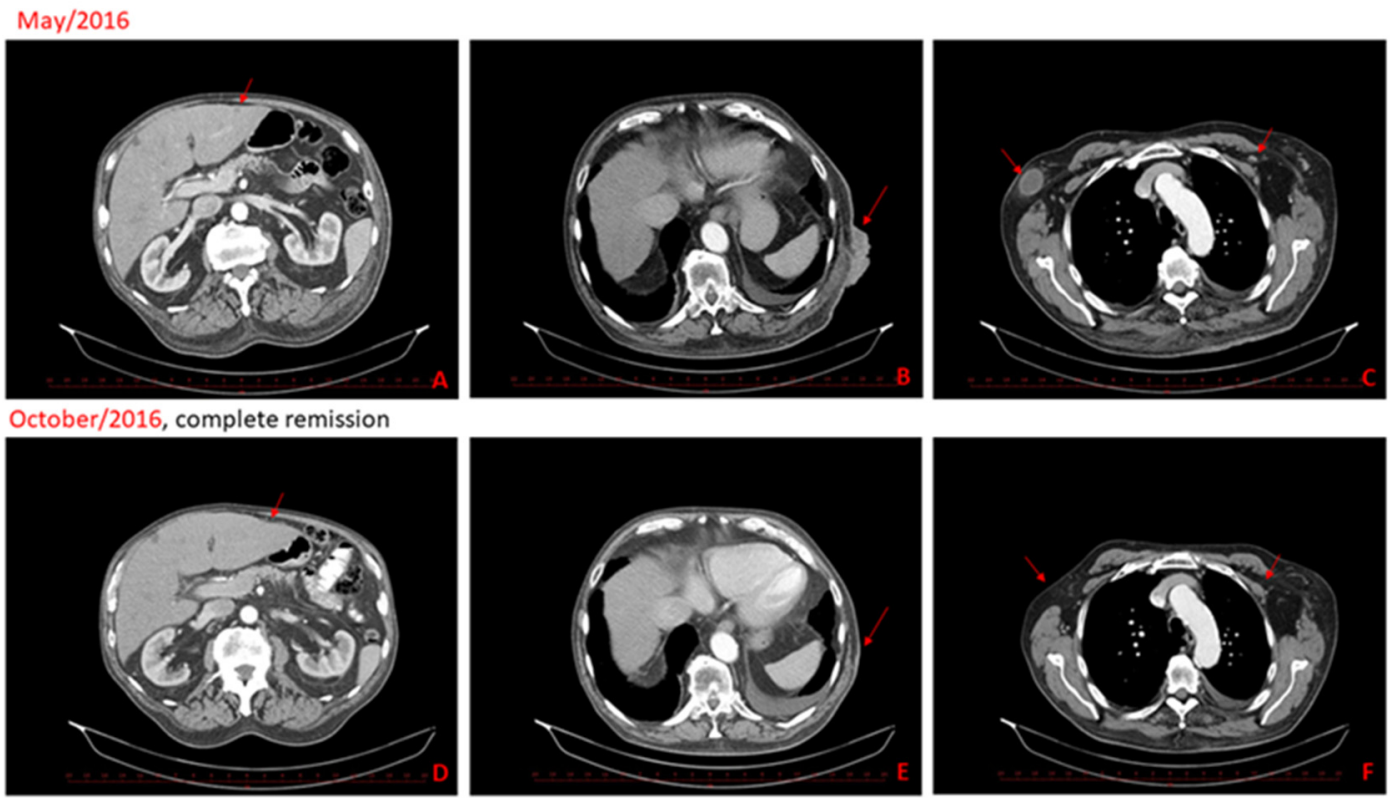

Figure 2. CT scans from May 2016 show progressive disease, new liver metastasis (A), skin and subcutaneous metastasis (B), left subclavicular node metastasis and right node axillary metastasis (C). CT scans in the second-line show complete remission of the metastatic disease, two months after cryotherapy and half a year after the last dose of ipilimumab (D-F).

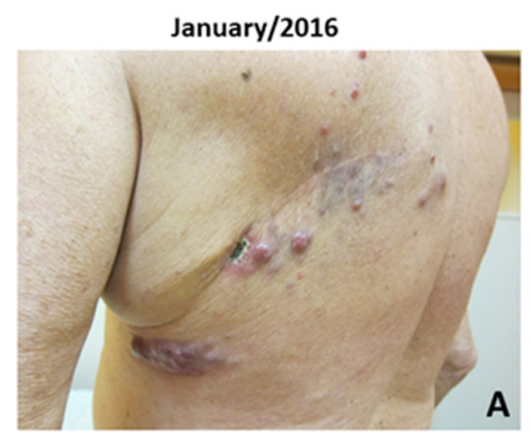

Jully/2016

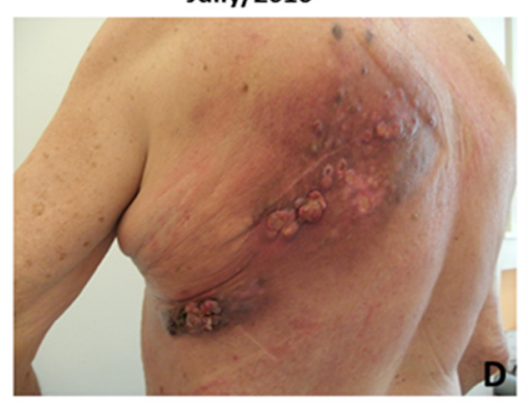

March/2016

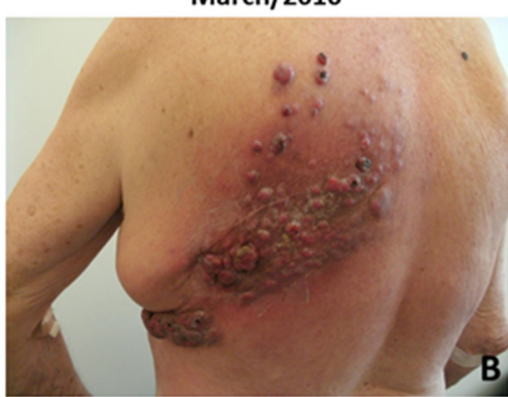

September/2016

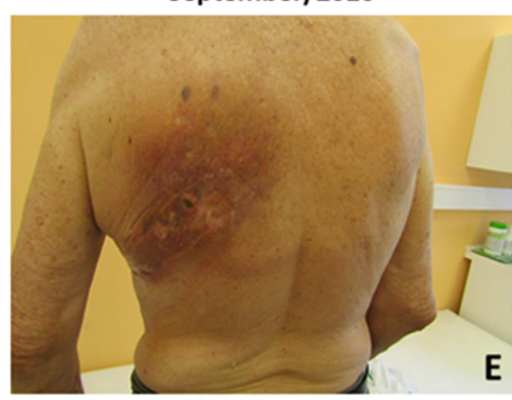

May/2016

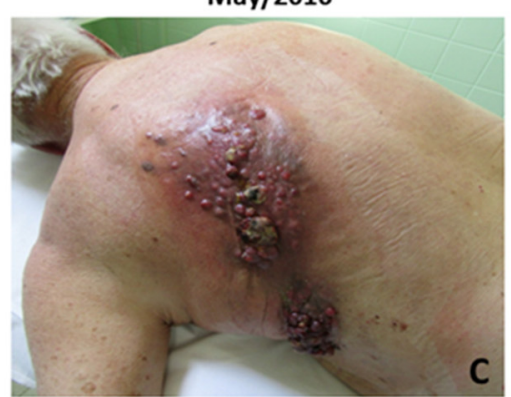

January/2017

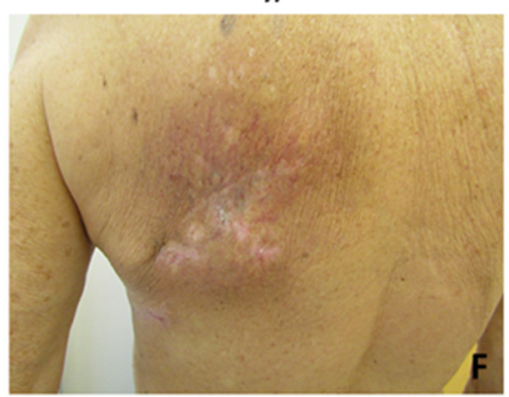

Figure 3. Clinical features at the beginning of ipilimumab therapy (A), after ipilimumab therapy cessation (B) and during perioperative preparation before cryotherapy (C). In the second row, we show clinical features during regression, before the 2nd cryotherapy (D), where partial regression was present, and the patient reported significant relief. Next, clinical pictures show practically healed skin lesions two months after cryotherapy (E), and already fully healed lesions on the back, where only scarring changes are visible, half a year after cryotherapy $(\mathbf{F})$. 


\subsection{Patient Follow Up}

Contrary to the situation before the cryotherapy, the cutaneous, liver and axillary lymph node metastases were not detected on the control CT scan (Figure 2D,F) two months after cryotherapy (approximately fourth months after the last ipilimumab administration). An excellent clinical response was apparent as early as two months after cryotherapy, where almost healed sites of cutaneous metastases were observed (Figure 3A-F). Excellent clinical response and fully healed skin lesions were documented during a regular follow-up visit six months after cryotherapy (Figure 3F). The complete response was maintained for 13 months after cryotherapy and 15 months after the last application of ipilimumab. The patient ceased suddenly due to myocardial infarction 15 months after cryotherapy, aged 79 , without any clinical signs of melanoma recurrence. The autopsy also did not show any recurrence of melanoma.

\subsection{Skin Biopsy and Immunohistochemistry}

Skin biopsies were obtained at three time points. First, before administering the first ipilimumab treatment dose (January 2016), second - after the fourth dose of ipilimumab (March 2016) and the third was taken at the beginning of the second cryosurgery (July 2016). The primary objective was the monitoring of TILs.

In the first biopsy, routine staining H\&E showed minimal intratumoral infiltration of TILs and irregular atypical tumour melanocytes before ipilimumab initiation (not shown). The second biopsy (after completing ipilimumab therapy) revealed a clear difference in the tumour melanocytes' morphology. We observed smaller, relatively regular and uniform tumour cells (not shown). In the third biopsy (after initial cryosurgery), massive necrosis and marked infiltration of immune cells were seen in the tumour centre (not shown).

Immunohistochemistry showed positivity for typical melanocytic/melanoma markers such as HMB45, MelanA/MART-1, tyrosinase and MiTF in the first biopsy (before ipilimumab, Figure 4A-D). In the second biopsy, only MiTF was positive, and other markers were negative (after ipilimumab, Figure $4 \mathrm{E}-\mathrm{H}$ ). The third biopsy was positive only for HMB45 in the tumour's vital periphery (after cryotherapy Figure 4I-L).
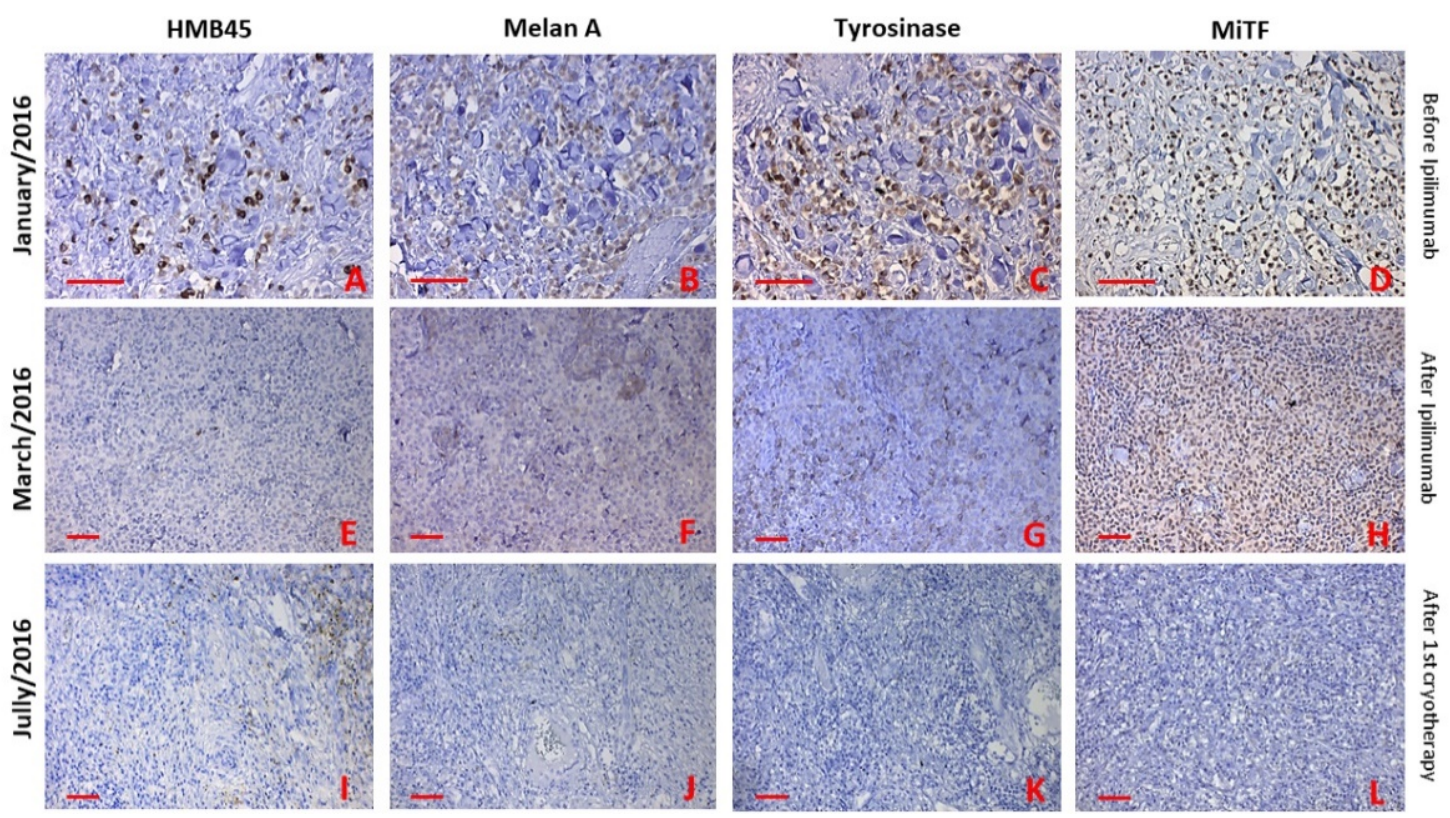

Figure 4. Immunohistochemical staining was performed to compare the phenotype of skin metastases, before initiation of ipilimumab therapy, after the last dose and after the first cryotherapy. The expression of all markers (HMB45, Melan A, Tyrosinase and MiTF) were present before initiation of ipilimumab therapy (A-D). MiTF and tyrosinase were only positive after the last dose of ipilimumab (G,H). HMB45 and Melan A were negative (E,F). Only HMB45 was positive in some melanoma cells at the edge of the necrotic tissue (I). Other markers were negative (J-L). Bar $50 \mu \mathrm{m}$. 
In the first biopsy, immunohistochemistry demonstrated biopsy diffuse very small infiltrate of $\mathrm{CD}^{+}$T-lymphocytes (TILs) and $\mathrm{CD}^{+} 8^{+}$macrophages and perivascular infiltrate of $\mathrm{CD} 45^{+}$T-lymphocytes (Figure 5A-C). In the second biopsy (after ipilimumab treatment) there was small infiltrate of $\mathrm{CD}^{+} \mathrm{T}$-lymphocytes at the periphery of the skin metastasis. This biopsy coincided with clinical progression of the disease. Virtually no infiltrate of CD45 ${ }^{+}$T-lymphocytes, and no CD68 ${ }^{+}$macrophages were seen (Figure 5D,F).
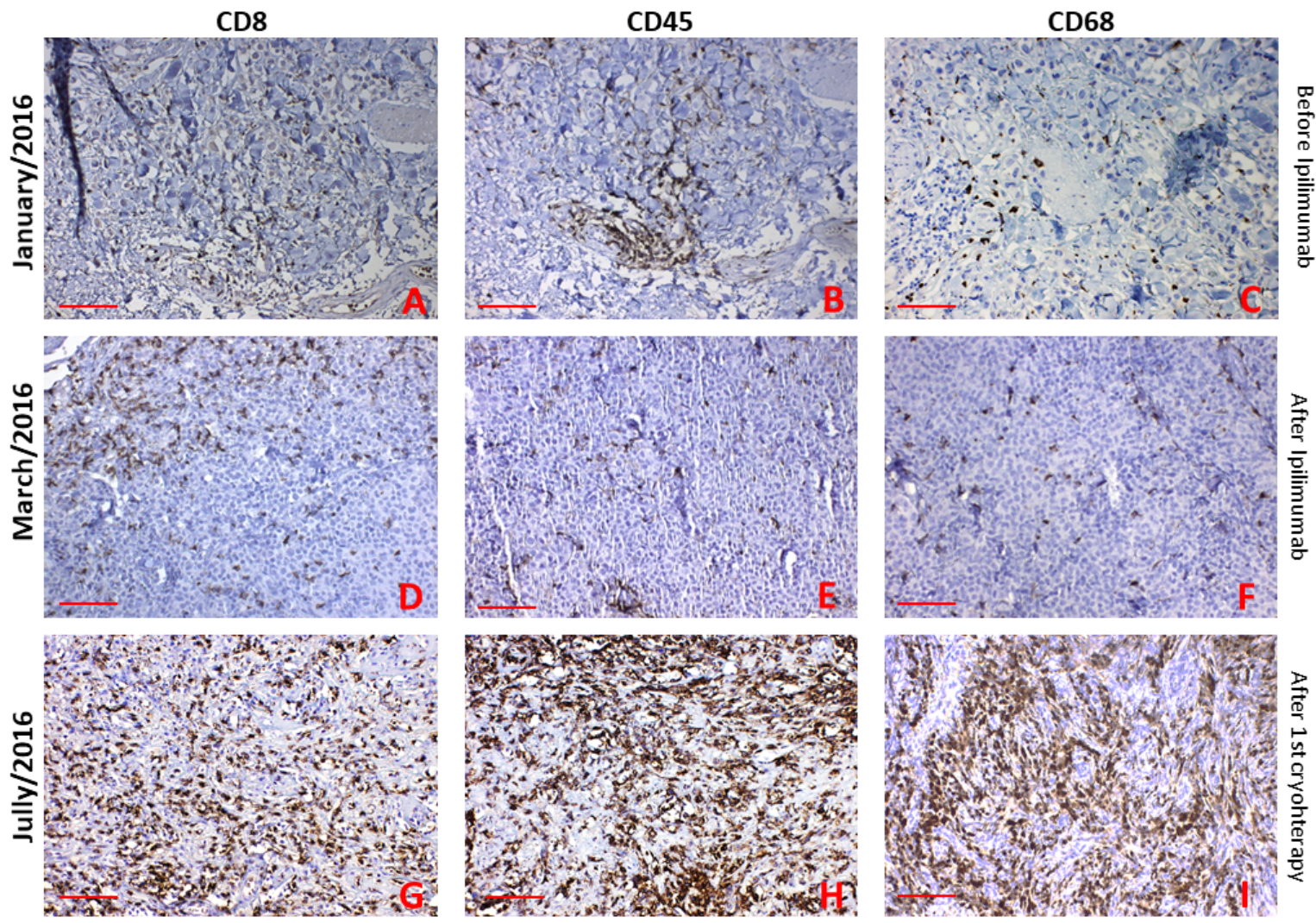

Figure 5. Immunohistochemical staining of TILs was also made. TILs were detected as only small perivascular infiltrate CD8 and CD45 positive cells before ipilimumab treatment $(\mathbf{A}, \mathbf{B})$. CD68 positive macrophages were seen as small diffuse infiltrate (C). CD8 positive T cells were observed at the edge of the tumour (D), and small diffuse infiltrates of CD45 and CD68 positive cells were observed after ipilimumab treatment $(\mathbf{E}, \mathbf{F})$. Significant and massive infiltrates of CD8, CD45 T cells and CD68 positive macrophages were observed in the skin metastasis after the first cryotherapy (G-I). Bar $50 \mu \mathrm{m}$.

In the biopsy one month after initial cryotherapy, we saw significantly increasing infiltration with $\mathrm{CD} 8^{+}$and $\mathrm{CD} 45^{+}$T-lymphocytes and $\mathrm{CD} 68^{+}$macrophages (Figure 5G-I).

\subsection{Blood Test, Tumour Markers}

Routinely used serological tumour markers such as S100B, LDH and CRP were used to follow the disease progression. The actual values of these biomarkers are presented in Figure 6. 


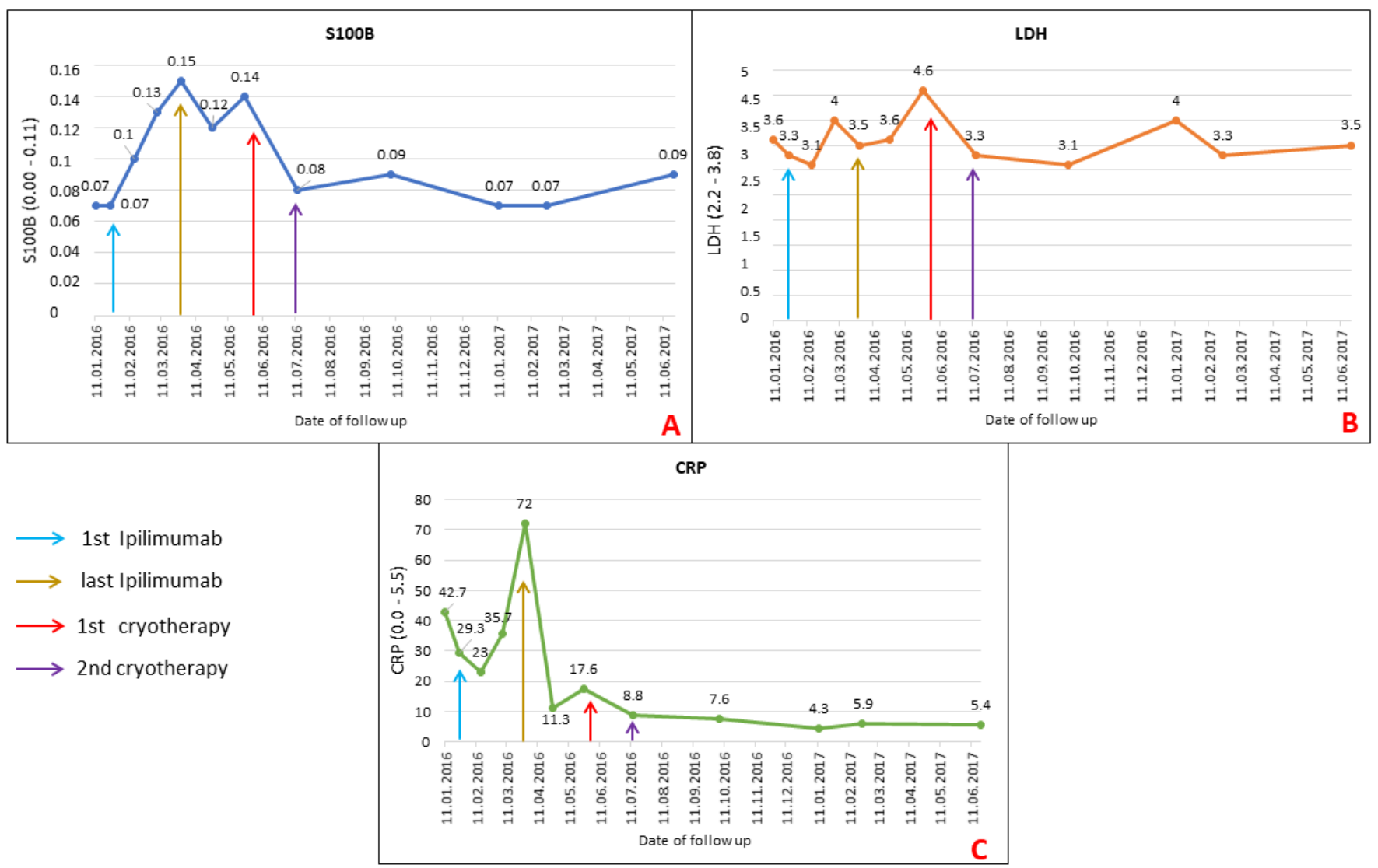

Figure 6. This figure shows the serological analysis of S100B, LDH and CRP during the patient's follow up. Graph A shows the elevation of S100B during clinical worsening and progression of metastatic disease at the ipilimumab therapy and the normalization of S100B values after cryotherapy. Similar results and values were observed for LDH (Graph B). In the case of CRP, significantly lower values were observed after completion of ipilimumab therapy, despite significant clinical progression (Graph C).

S100B and LDH show elevation above the normal value at the end of ipilimumab therapy during clinical progression and decline to normal after cryotherapy and subsequent regular follow-ups (Figure 6A,B).

The value of CRP increased during ipilimumab therapy and, surprisingly, decreased after the end of ipilimumab treatment before cryotherapy (Figure 6C). However, there was an inflammatory response in the vicinity of skin metastases.

Despite the relatively good clinical and laboratory status before initiating ipilimumab therapy, the neutrophil to lymphocyte ratio (NLR) was unfavourable. The NLR was 3.69 (Neutrophils abs.: 4.99 [2.00-7.00]/Lymphocytes abs.: 1.35 [0.80-4.00]) before initiating ipilimumab therapy, and NRL was 1.74 (Neutrophils abs.: 3.66/Lymphocytes abs.: 2.10) (for details and reference values see Table 1 ) at the end of this therapy. Although it is not a factor that excludes checkpoint inhibitor therapy, NLR may be a helpful biomarker of the overall therapeutic response and time to progression-free survival (PFS) or overall survival (OS) [30]. 
Table 1. Serological and blood count markers used and their laboratory standard deviations, and critical values (Institute of Medical Biochemistry and Laboratory Diagnostics, General University Hospital and First Faculty of Medicine, Charles University, Prague, Czech Republic).

\begin{tabular}{ccccc}
\hline Serological Analysis & $\begin{array}{c}\text { Lower Value } \\
\text { Limit }\end{array}$ & $\begin{array}{c}\text { Uper Value } \\
\text { Limit }\end{array}$ & $\begin{array}{c}\text { Critical Value } \\
\text { Limit }\end{array}$ & Units \\
\hline S100B & 0.00 & 0.11 & 1 & $\mathrm{~g} / \mathrm{L}$ \\
\hline LDH & 2.20 & 3.80 & 15.00 & $\mu \mathrm{kat} / \mathrm{L}$ \\
\hline CRP & 0.00 & 5.50 & 100.00 & $\mathrm{mg} / \mathrm{L}$ \\
\hline Blood count & & & & \\
\hline Neutrophils abs & 2.00 & 7.00 & 50.00 & $10^{9} / \mathrm{L}$ \\
\hline Lymphocytes abs & 0.80 & 4.00 & 7.20 & $10^{9} / \mathrm{L}$ \\
\hline
\end{tabular}

\section{Discussion}

Ipilimumab has shown significant improvement in OS in metastatic and advanced melanoma in two randomized, phase 3 clinical trials with response rates of $10-15 \%[1,31]$. Although the figure is relatively low, it was a pioneer drug and undisputed promise for a new melanoma immunotherapy trend. In our case, we also observed progression on CT scans and organ metastasis early after the last ipilimumab dose administration.

In later years, several studies have sought to increase the effect of ipilimumab. Recently, the most effective is the combination of two checkpoint inhibitors, ipilimumab and antiPD-1 inhibitor nivolumab [2].

Further desirable potentiation of checkpoint inhibitors therapy can also be achieved by radiotherapy [19]. Unfortunately, only some patients can benefit from this stimulation of the immune system with an anti-tumour effect. Due to disease dissemination, we did not choose radiotherapy in our case.

The systemic anti-tumour effect induced by focal radiotherapy, generally referred to as the abscopal effect, cannot be easily predicted by any biomarker. Chandra and coworkers described the benefit of combined radiotherapy and ipilimumab with a median OS of 28 months, compared with a median OS of 11.4 months in the clinical trial with ipilimumab [32]. Grimaldi and co-workers describe the abscopal effect in 21 patients who progressed after ipilimumab and received radiotherapy. In 11 patients (52\%), the abscopal effect was observed, including nine who had a partial response (PR) and two that had stable disease (SD). The median overall survival (OS) for patients with the abscopal effect was 22.4 months vs. 8.3 months for patients who did not experience this effect [33].

However, the optimal induction of anti-tumour immunity and radiotherapy's abscopal effect is not established in clinical practice. Recently, studies have suggested that adequate stimulation of the immune system can be achieved by a single dose of $15 \mathrm{~Gy}$ fraction. It is a sub-curative dose, which can slow the tumour growth as a dynamic balance between tumour proliferation and $\mathrm{CD}^{+} \mathrm{T}$ cell-mediated tumour-cell apoptosis [34,35]. Another preclinical study demonstrated the best induction of anti-tumour immunity using hypofractionation (three times $8 \mathrm{~Gy}$ ) radiotherapy [35,36].

To summarise, the median radiotherapy dose used in patients after ipilimumab was 26 Gy (range: 8-68 Gy), and the median fraction size was 4 Gy (range: 1.8-25 Gy). The median time between radiotherapy and ipilimumab was one month [19]. The effect of stereotactic ablative body radiotherapy (SABR) has also been published to improve anti-tumour activity stimulation and control disease-free survival in multiple clinical studies [37,38].

Some tumours lack the appropriate inflammatory cytokines and chemokines to attract immune cells, such as DCs, macrophages and cytotoxic T cells, to the tumour site. Indeed, we have also observed this phenomenon in the initial biopsy. On the other hand, the expression of immunosuppressive ligands and death ligands inhibits $\mathrm{T}$ cells' function and activation of the anti-tumour effect [39]. The downregulation of adhesion molecules, 
such as vascular cell adhesion molecule 1 (VCAM1) and intercellular adhesion molecule 1 (ICAM1), in the tumour microenvironment can inhibit $\mathrm{T}$ cell migration to the tumour site. On the other hand, these molecules' expression promotes cell invasion and metastasis and is associated with a worse prognosis in melanoma patients $[40,41]$.

Radiotherapy can promote the release of tumour neoantigens and potentially lead to the stimulation of immune responses with an anti-tumour effect. Reits and co-workers observed that radiotherapy at doses 10-26 Gy could enhance MHC-I expression in vitro and in vivo studies. This fact increased the presentation of tumour antigens and stimulated $\mathrm{T}$ cell attack to the tumour site [42]. The next anti-tumour activity of radiotherapy can occur by introducing Fas ligands expression and ICAM-1 molecule on tumour cells, making tumour cells more sensitive to T cell-mediated lysis [43].

The change in the tumour microenvironment by radiotherapy is relatively fundamental. Localized radiotherapy induces a burst release of cytokines and chemokines, giving rise to an inflammatory tumour microenvironment. The main factor is the strengthening of interferons' expression (IFNs), crucial for anti-tumour immune response. Type I IFN is essential for the activation and function of DCs and T cells, which, in turn, is responsible for the release of IFN- $\gamma$ and tumour control. Inhibition of expression IFN- $\gamma$ is one of many factors responsible for resistance to immunotherapy by checkpoint inhibitors [44,45].

Radiotherapy induces cell apoptosis called immunogenic cell death (ICD). This type of apoptosis responds to the release of tumour neoantigens for stimulation of antigenpresenting cells (APCs). It is the stimulation of these cells that is responsible for the possible systemic immune response and the induction of the abscopal effect [46]. Calreticulin is a molecule transported from the endoplasmatic reticulum to the cell surface due to radiotherapy's stress factors. This expression may by the signal for APCs, resp. DCs for phagocytosis of damaged cells by radiotherapy [47]. Another molecule is adenosine triphosphate (ATP), which can attract monocytes and DCs to tumours by a purinergic receptor P2 $\times 7$-dependent pathway and promote the secretion of pro-inflammatory cytokines such as IL-1 $\beta$ and IL-18 [48]. During activation of anti-tumour immunity and pro-inflammatory microenvironment, Toll-like receptors play a significant role by binding to a molecule such as HMGB1 (high-mobility group box protein 1). This expression is associated with tumour cell stress after radiotherapy [49]. After stimulation of DCs with neoantigens, these cells migrate to lymph nodes to present the neoantigens to $\mathrm{T}$ cells by MHC molecules pathway and T cell receptors. The primary activation is the stimulation of $\mathrm{CD}^{+} \mathrm{T}$ cells, which are crucial effectors in anti-tumour immunity. However, the MHC pathway is a complex of interactions that, alone, are insufficient to lead to $T$ cells' activation. Subsequent activation is necessary for co-stimulatory signals, such as the expression of CD80, CD40 L, and CD28 [50]. O ne dominant negative immunomodulatory receptor is cytotoxic T lymphocyte-associated antigen 4 (CTLA-4). It can also combine with CD80 and CD86 and attenuate T cell activation. Targeted blockade of the CTLA-4 receptor allows stimulation of the immune system with a systemic anti-tumour effect after stimulation with tumour neoantigens [51]. Therefore, the combination of ipilimumab and radiotherapy (or other modalities to induce cell lysis and release neoantigens) helps potentiate the systemic anti-tumour effect and, in some cases, also the abscopal effect $[17,19,33]$. In the case of programmed cell death 1 (PD-1), it is expressed in T cells' plasma membranes, DCs and NK cells. PD-1 interacted with ligands, PD-L1 and PD-L2, which are ideally expressed in tumour cells. In some tumours, such as non-small cell lung cancers, PD-L1 expression is essential for PD-1 inhibitors therapy [52,53]. PD-L1 is not routinely investigated in melanoma, and even patients without expression may have an excellent therapeutic response to PD-1 inhibitors, however, worse than in patients with fully expressed expression [2]. The upregulation of PD-L1 can be observed in mouse breast cancer and colon adenocarcinoma tumour mouse models [54]. In this vein, the combination of checkpoint inhibition by PD-1/PD-L1 can be enhanced by radiotherapy to achieve a systemic antitumour effect. Park and co-workers investigated the influence of PD-1 expression on the systemic anti-tumour response with abscopal effect induced by SABR in preclinical mouse 
melanoma and renal cell carcinoma models. SABR induces a tumour-specific immune response in the irradiated and non-irradiated (abscopal) tumours, potentiated by PD-1 blockade [35]. Tsui and co-workers describe a patient with mucosal melanoma treated with adjuvant radiotherapy (50 Gy, 20 fractions) and with palliative radiotherapy by $24 \mathrm{~Gy}$ in 3 fractions ( 0,7 and 21. day) for neck lymph node progression of metastatic disease after pembrolizumab [55].

Cryotherapy with liquid nitrogen is a possible option to treat non-melanoma skin cancers such as basal cell carcinoma [56]. In melanoma, cryosurgery can be used as a palliative treatment of skin metastases, to a limited extent of liver metastases. It can be a helpful option during surgical extirpation or adjuvant therapy of conjunctival melanoma [57-59].

The direct cellular injury in cryotherapy is due to the freezing of water, leading to disruptive necrosis and water transmembrane movement. Of note, thawing is also associated with cellular damage and can be equally destructive. The mechanisms by which cryoablation kills cells are therefore multiple and complex. Mechanistically, the cooling and warming rate during cryosurgery has a significant impact on extracellular and intracellular ice formation and also osmotic changes. In our case, we have indeed observed massive necrosis and marked infiltration of immune cells in the third presented biopsy (Figure 4I-L).

The release of many tumour neoantigens induced by necrosis due to cryotherapy could be one of the main reasons for the stimulation of the immune system and the abscopal effect in our case. Our observation can support this, because we have seen significantly increasing infiltration with $\mathrm{CD} 8^{+}, \mathrm{CD}^{+} 5^{+}$and $\mathrm{CD}^{+} 8^{+}$cells in tumours and their vicinity after cryotherapy (Figure 5G-I).

The attention of contemporary immunooncology is primarily focused on the aspects of the adaptive immune response following cryosurgery [60]. However, the initial immunologic consequence of cryoablation is the initiation of a purely nonspecific innate response.

Gazzaniga and co-workers observed a quick infiltrative response of polymorphonuclear leukocytes around the cryoablated tumours in a murine model in the first $24 \mathrm{~h} \mathrm{[61].}$ The neutrophilic infiltration was peaking at day three and was consequently replaced by extensive macrophage recruitment which was present after day three. Notably, the authors observed that an early intratumoral immune cell infiltration was detected only in animals receiving recombinant murine granulocyte macrophage- colony-stimulating factor $24 \mathrm{~h}$ after cryoablation of xenotransplanted melanoma.

Macrophages are a critically important cell type in the clearance of necrotic tissue. Moreover, macrophages are also active players in immunomodulation after cryoablation. Macrophages secrete various cytokines that can attract, activate and further orchestrate multiple other immune cells. Of note, macrophages are highly heterogeneous in these activities. In the last decades, the remarkable plasticity of macrophages in response to different environments was gradually studied, and the concept of M1/M2 polarization was broadly accepted [62]. M1 macrophages, also known as classically activated macrophages, are pro-inflammatory and have a central role in host defence against infection. On the contrary, M2 macrophages, known alternatively as activated macrophages, are associated with responses to anti-inflammatory reactions and tissue remodelling. The transformation of naïve macrophages to different phenotypes depends on the context of the tissue microenvironment. M1 and M2 macrophages represent only two terminals of the full spectrum of macrophage activation. In the context of tumour biology, another important subgroup attracted the attention of immunologists - tumour associated macrophages. These macrophages help tumour cells escape from being killed and support them in spreading to other tissues and organs [63].

In non-infectious inflammations, such as cryoablation injury, damage-associated molecular patterns (DAMPs) such as DNA and heat shock proteins (HSPs) from damaged or dying cells can stimulate Toll-like receptors of macrophages and dendritic cells, leading to the release of various cytokines, namely IL-6 as a key secreted cytokine. 
It was observed that the number of local infiltrated macrophages and serum IL-6 levels peaked at day 7 and decreased at day 14 after cryoablation [64]. Gu and co-workers also suggested here that post-cryosurgery serum IL-6 increase is mainly due to infiltrating macrophages. Of note, we can confirm these CD68 positive macrophages also in the later stage (Figure 5I, one month after cryotherapy).

Takahashi and co-workers used cryosurgery in the mouse melanoma and Lewis lung carcinoma model. This study suggested that cryosurgery generates the most favourable immune-regulatory response for abscopal tumours and activation of anti-tumour immune cells, and increased secretion of pro-inflammatory cytokines such as IL-1 $\beta$, IL-2, IL-6, IL$12 \beta$, IFN- $\gamma$ and TNF- $\alpha$. The infiltration of $\mathrm{CD}^{+}$and $\mathrm{CD}^{+} \mathrm{T}$ cells in the abscopal tumour was also significantly higher [65].

Mechanistically, cryosurgery results in an acute response of the tissue similarly to normal wounding. Following the lysis of tumour cells, tumour-derived antigens are released. Highlighting this boosting effect of cryosurgery, some authors have referred to this ability of cryotherapy to load dendritic cells and consequently present to effectors as producing an "in-vivo dendritic cell vaccine" [66]. After cryotherapy tumour antigens, the immune system's primary stimulated with anti-CTLA-4, and anti-PD-1 resulted in a robust cytotoxic $\mathrm{CD} 8^{+} \mathrm{T}$-cell response with a potential systemic effect [22].

However, the tumour microenvironment, including malignant melanoma, is very similar to that of a chronic wound $[67,68]$. This microenvironment has a stimulatory effect on melanoma cells growth and migration [69]. Of note, this microenvironment represents a highly dynamic system. As cryotherapy represents the acute phase of wounding, its "healing" is associated with time-limited activation of immune system in order to remove tissue debris and minimize risk of infection [70]. This also establishes a new immune equilibrium and changes the tumour promoting setting of the cancer-associated microenvironment.

We can hypothesize that the wound healing-dependent activation of immune response in cryo-ablated tumour tissue can synergize with immune checkpoint inhibition such as anti-CTLA-4/ipilimumab therapy of melanoma.

\section{Methods and Materials}

\subsection{Cryotherapy and Sample Collection}

Cryotherapy applying extremely cold cryogen $\left(-196^{\circ} \mathrm{C}\right.$, liquid nitrogen) to destroy metastatic tissues was performed using contact Cryocauter ( $\mathrm{KCH} 450$ Automat, Czech Republic). First, we made a shave excision of five bleeding exophytic metastases to achieve a more reliable cryodestruction. Every metastasis base was cryocauterised by the method of partially overlapping fields; every field was exposed twice for $30 s$ to $-189^{\circ} \mathrm{C}$ with tissue warming up to $37^{\circ} \mathrm{C}$ in between. The photodocumentation was performed during the first cryotherapy (Figure 1C). The second cryotherapy was completed one month later using the same procedure as above. The significant reduction of skin metastasis was evident (Figure 1D). The biopsies of skin metastasis were taken before ipilimumab initiation, during progression after ipilimumab cessation, and one month after the first cryotherapy to control the effect of immunotherapy. We also made a blood test for tumour markers such as S100B protein and lactate dehydrogenase (LDH) and C-reactive protein (CRP) at each clinical examination. According to the Declaration of Helsinki, all tissue samples, blood samples, clinical photography and CT scans were obtained after attaining informed consent with the local ethical committee's agreement.

\subsection{Immunohistochemistry}

Tissue samples were fixed for $24-48 \mathrm{~h}$ in $4 \%$ neutral buffered formalin at room temperature and routinely processed to paraffin blocks. Sections ( $3 \mu \mathrm{m}$ thickness) were deparaffinized and rehydrated through xylene and ethanol, and PBS. Afterwards, heat-induced epitope retrieval was performed using citrate buffer $\left(\mathrm{pH}\right.$ 6.0) in an autoclave at $120^{\circ} \mathrm{C}$ for $3 \mathrm{~min}$ with consequent gradual cooling to room temperature over $60 \mathrm{~min}$. Unspecific binding of antibodies was inhibited using Protein Block system (Dako; Agilent Technolo- 
gies, Inc., Santa Clara, CA, USA; cat. no. X0909) followed by treatment with 3\% hydrogen peroxide (diluted in PBS; Sigma Aldrich; Merck KGaA) for $20 \mathrm{~min}$. Sections were incubated overnight at $4{ }^{\circ} \mathrm{C}$ with biotinylated primary antibodies (manufacturer-validated summary antibody information in Table 2; the manufacturer validated all employed antibodies for use in these methods). The next day, sections were extensively washed in running water and incubated with a secondary (polymer HRP-tagged) antibody. DAB (3,3'-Diaminobenzidine) chromogen was used for visualization of immunohistochemical reaction according to the standard protocol. Nuclei were counterstained with Gill's haematoxylin and mounted in Pertex (Biotech, Prague, Czech Republic).

Table 2. Antibodies used for immunohistochemical analysis.

\begin{tabular}{cc}
\hline Primary Antibody (Clone No.) & Supplier (Location) \\
\hline MiTF (Clone D5), MoMoAb, 1:100 & Dako, Agilent Technologies, Inc. (Santa Clara, \\
CA, USA) \\
HMB45 (Clone HMB-45), MoMoAb, 1:100 \\
MiTF (Clone D5), MoMoAb, 1:100 \\
MELAN A (A103), MoMoAb, 1:100 \\
CD68 (M0814), MoMoAb, 1:100 \\
$\begin{array}{cc}\text { CD45 (SAB4502541) RaMoAb, 1:200 } \\
\text { CD8 (Clone SP239), RaMoAb, 1:100 }\end{array}$ \\
\hline Secondary Antibody (Clone No.) & Sigma-Aldrich, Prague, Czech Republic \\
\hline N-Histofine Simple Stain MAX PO (414152F) & EXBIO Prague s.r.o. (Prague, Czech Republic) \\
\hline Chromogen & Supplier (Location) \\
\hline DAB (3,3'-Diaminobenzidine) & Dako, Agilent Technologies, Inc. (Santa Clara, \\
CA, USA)
\end{tabular}

\subsection{Serological Analysis and Blood Count}

All serological tests and blood counts were performed during routinely scheduled examinations as recommended for patients during follow-up after immunotherapy. Blood tests were performed in an accredited university hospital laboratory (Institute of Medical Biochemistry and Laboratory Diagnostics, General University hospital and First Faculty of Medicine, Charles University, Prague, Czech Republic). The laboratory complies with national accreditation standards (ČSN, EN ISO 15189; 2013), which guarantee the accuracy of verified results. Normal value range and pathological limits were determined by the producer. S100B (Roche, Switzerland) was performed by Electro-chemiluminescence immunoassay (ECLIA) for the in vitro quantitative determination of S100 in human serum. LDH (Roche, Switzerland) was performed by International Federation of Clinical Chemistry (IFCC) methods, and CRP (Roche) was performed by nephelometry using a Dade Behring BNII instrument. Blood count, neutrophils abs. and lymphocytes abs. were performed by automatic analyzer. The serological markers used, and the examination of the blood count, physiological limits and critical values are summarized in Table 1.

\section{Conclusions}

The abscopal effect is mediated by a systemic anti-tumour immune response elicited by focal treatment and followed by regression at distant sites (Figure 1). The abscopal effect was observed mainly after radiotherapy. Recently, it is possible to use targeted oncolytic viruses (e.g., T-VEC), which promote anti-tumour immune responses that lead to the abscopal regression of distant metastases [71]. Other options for the local treatment of patients with solid tumours include intratumorally applied cytotoxic proteins, photodynamic therapy, laser therapy, electroablation and high-intensity focused ultrasonography. 
The biological rationale behind the abscopal effect triggering remains unclear. However, the great success of immunotherapy achieved in melanoma recently also reignited interest in the abscopal effect. The discussed studies with the achieved abscopal effect are summarized in Table 3.

Table 3. Key works that have been discussed and where the abscopal effect has been observed were summarized.

\begin{tabular}{llll}
\hline Inductor & Clinical/Experimental & Checkpoint Inhibitor & Reference \\
\hline Radiotherapy & Clinical & Anti-CTLA-4 & {$[19,32,33]$} \\
\hline Radiotherapy & Experimental (mice) & Anti-PD1 & {$[35]$} \\
\hline Radiotherapy & Clinical & Anti-PD1 & {$[55]$} \\
\hline Thermal ablation & Experimental & Anti-CTLA4/Anti-PD1 & {$[60]$} \\
\hline T-VEC & Clinical & Not used/Anti-PD1 & {$[28,71]$} \\
\hline
\end{tabular}

Our case report presents the successes achieved with immunotherapy and cryotherapy in combination. The induction of a systemic response with an abscopal effect by cryotherapy is rare even though the immune system's stimulation is similar to radiotherapy or oncolytic viruses $[18,72]$. The combination of costly immunotherapy with more affordable methods could beneficially increase therapeutic outcomes at least in some patients. However, we are recently lacking reliable biomarkers predicting such a favorable response.

Author Contributions: Conceptualization: K.S.J., O.K. and L.L.; data collection: K.S., K.N., A.H., O.K., P.D., I.K., L.L., and J.Š., writing original draft preparation: O.K., K.S.J., L.L.; histology and immunohistochemistry: O.K., K.N., P.D., J.Š., funding acquisition: L.L and K.S.J. All authors have read and agreed to the published version of the manuscript.

Funding: This research was funded by the project "Centre for Tumour Ecology-Research of the Cancer Microenvironment Supporting Cancer Growth and Spread" (No. CZ.02.1.01/0.0/0.0/16_ 019/0000785), supported by the Operational Programme "Research, Development and Education" and by project of Charles University in Prague (PROGRES Q28).

Institutional Review Board Statement: The study was conducted according to the guidelines of the Declaration of Helsinki, and approved by the Institutional Ethics Committee of General University Hospital in Prague (protocol code 22/14/2014) at 25 March 2014).

Informed Consent Statement: Informed consent was obtained from subject involved in the study.

Data Availability Statement: The data are available in author's archive.

Acknowledgments: The authors are grateful to Šárka Takáčová for the language revision of the manuscript.

Conflicts of Interest: The authors declare no conflict of interest.

\section{Abbreviations}

Aside from official gene names, the following abbreviations were used in-text and legends:

APCs Antigen-presenting cells

ATP Adenosine triphosphate

CD4 Cluster of differentiation 4

CD8 Cluster of differentiation 8

CD28 Cluster of Differentiation 28

CD $40 \quad$ Cluster of differentiation 40

CD48 Cluster of Differentiation 48 (B-lymphocyte activation marker)

CD68 Cluster of Differentiation 68

CD $80 \quad$ Cluster of differentiation 80 


$\begin{array}{ll}\text { CRP } & \text { C-reactive protein } \\ \text { CT } & \text { Computed Tomography } \\ \text { CTLA-4 } & \text { Cytotoxic T-lymphocyte antigen 4, CD152 } \\ \text { DAMPs } & \text { Damage-associated molecular patterns } \\ \text { DAB } & \text { 3:3'-Diaminobenzidine } \\ \text { DCs } & \text { Dendritic Cells } \\ \text { Gy } & \text { Gray (unit) } \\ \text { H\&E } & \text { Hematoxylin eosin staining } \\ \text { HMGB1 } & \text { HMGB1 } \\ \text { HRP } & \text { horseradish peroxidase } \\ \text { ICAM1 } & \text { Intercellular Adhesion Molecule 1 } \\ \text { ICD } & \text { Immunogenic cell death } \\ \text { IFNs } & \text { Interferons } \\ \text { IFN- } \gamma: & \text { Interferon gamma } \\ \text { IL } & \text { Interleukin } \\ \text { IL-1 } \beta & \text { Interleukin 1 beta } \\ \text { IL-18 } & \text { Interleukin 18 } \\ \text { IL-2: } & \text { Interleukin 2 } \\ \text { IL-6: } & \text { Interleukin 6 } \\ \text { IL-12 } 3: & \text { Interleukin 12 beta } \\ \text { IPRES } & \text { Innate PD-1 RESistance } \\ \text { LDH } & \text { Lactate dehydrogenase } \\ \text { MHC } & \text { Major histocompatibility complex } \\ \text { NK } & \text { Natural killer cell } \\ \text { NRL } & \text { Neutrophil to lymphocyte ratio } \\ \text { ORR } & \text { Objective response rate } \\ \text { OS } & \text { Overall survival } \\ \text { P2 } \times 7 & \text { P2X purinoceptor 7 } \\ \text { PBS } & \text { Phosphate-buffered saline } \\ \text { PD-1 } & \text { Programed cell death 1, CD279 } \\ \text { PFS } & \text { Progression free survival } \\ \text { SD } & \text { Stable disease } \\ \text { S100B } & \text { S100 calcium-binding protein B } \\ \text { TAMs } & \text { Tumor-associated macrophages } \\ \text { TILs } & \text { Tumor-infiltrating lymphocytes } \\ \text { TNF- } \alpha . & \text { Tumor necrosis factor alfa } \\ \text { VCAM1 } & \text { Vascular cell adhesion protein 1 } \\ & \end{array}$

\section{References}

1. Hodi, F.S.; O'Day, S.J; McDermott, D.F.; Weber, R.W.; Sosman, J.A.; Haanen, J.B.; Gonzalez, R.; Robert, C.; Schadendorf, D.; Hassel, J.C.; et al. Improved Survival with Ipilimumab in Patients with Metastatic Melanoma. N. Engl. J. Med. 2010, 363, 711-723. [CrossRef]

2. Larkin, J.; Chiarion-Sileni, V.; Gonzalez, R.; Grob, J.J.; Rutkowski, P.; Lao, C.D.; Cowey, C.L.; Schadendorf, D.; Wagstaff, J.; Dummer, R.; et al. Five-Year Survival with Combined Nivolumab and Ipilimumab in Advanced Melanoma. N. Engl. J. Med. 2019, 381, 1535-1546. [CrossRef]

3. Jiang, T.; Shi, T.; Zhang, H.; Hu, J.; Song, Y.; Wei, J.; Ren, S.; Zhou, C. Tumor Neoantigens: From Basic Research to Clinical Applications. J. Hematol. Oncol. 2019, 12, 1-13. [CrossRef]

4. Huang, J.; El-Gamil, M.; Dudley, M.E.; Li, Y.F.; Rosenberg, S.A.; Robbins, P.F. T Cells Associated with Tumor Regression Recognize Frameshifted Products of the CDKN2A Tumor Suppressor Gene Locus and a Mutated HLA Class I Gene Product. J. Immunol. 2004, 172, 6057-6064. [CrossRef]

5. Bonaventura, P.; Shekarian, T.; Alcazer, V.; Valladeau-Guilemond, J.; Valsesia-Wittmann, S.; Amigorena, S.; Caux, C.; Depil, S. Cold Tumors: A Therapeutic Challenge for Immunotherapy. Front. Immunol. 2019, 10, 168. [CrossRef] [PubMed]

6. Nowicki, T.S.; Hu-Lieskovan, S.; Ribas, A. Mechanisms of Resistance to PD-1 and PD-L1 Blockade. Cancer J. 2018, 24, 47-53. [CrossRef] [PubMed] 
7. Hugo, W.; Zaretsky, J.M.; Sun, L.; Song, C.; Moreno, B.H.; Hu-Lieskovan, S.; Berent-Maoz, B.; Pang, J.; Chmielowski, B.; Cherry, G.; et al. Genomic and Transcriptomic Features of Response to Anti-PD-1 Therapy in Metastatic Melanoma. Cell 2016, 165, 35-44. [CrossRef] [PubMed]

8. Ayers, M.; Lunceford, J.; Nebozhyn, M.; Murphy, E.; Loboda, A.; Kaufman, D.R.; Albright, A.; Cheng, J.D.; Kang, S.P.; Shankaran, V.; et al. IFN- $\gamma$-Related MRNA Profile Predicts Clinical Response to PD-1 Blockade. J. Clin. Investig. 2017, 127, $2930-2940$. [CrossRef]

9. Vilain, R.E.; Menzies, A.M.; Wilmott, J.S.; Kakavand, H.; Madore, J.; Guminski, A.; Liniker, E.; Kong, B.Y.; Cooper, A.J.; Howle, J.R.; et al. Dynamic Changes in PD-L1 Expression and Immune Infiltrates Early during Treatment Predict Response to PD-1 Blockade in Melanoma. Clin. Cancer Res. 2017, 23, 5024-5033. [CrossRef]

10. Snyder, A.; Makarov, V.; Merghoub, T.; Yuan, J.; Zaretsky, J.M.; Desrichard, A.; Walsh, L.A.; Postow, M.A.; Wong, P.; Ho, T.S.; et al. Genetic Basis for Clinical Response to CTLA-4 Blockade in Melanoma. N. Engl. J. Med. 2014, 371, 2189-2199. [CrossRef] [PubMed]

11. Gao, J.; Shi, L.Z.; Zhao, H.; Chen, J.; Xiong, L.; He, Q.; Chen, T.; Roszik, J.; Bernatchez, C.; Woodman, S.E.; et al. Loss of IFN- $\gamma$ Pathway Genes in Tumor Cells as a Mechanism of Resistance to Anti-CTLA-4 Therapy. Cell 2016, 167, 397-404. [CrossRef]

12. McGranahan, N.; Furness, A.J.S.; Rosenthal, R.; Ramskov, S.; Lyngaa, R.; Saini, S.K.; Jamal-Hanjani, M.; Wilson, G.A.; Birkbak, N.J.; Hiley, C.T.; et al. Clonal Neoantigens Elicit T Cell Immunoreactivity and Sensitivity to Immune Checkpoint Blockade. Science 2016, 351, 1463-1469. [CrossRef] [PubMed]

13. Greenman, C.; Stephens, P.; Smith, R.; Dalgliesh, G.L.; Hunter, C.; Bignell, G.; Davies, H.; Teague, J.; Butler, A.; Stevens, C.; et al. Patterns of Somatic Mutation in Human Cancer Genomes. Nature 2007, 446, 153-158. [CrossRef]

14. Gros, A.; Parkhurst, M.R.; Tran, E.; Pasetto, A.; Robbins, P.F.; Ilyas, S.; Prickett, T.D.; Gartner, J.J.; Crystal, J.S.; Roberts, I.M.; et al. Prospective Identification of Neoantigen-Specific Lymphocytes in the Peripheral Blood of Melanoma Patients. Nat. Med. 2016, 22, 433-438. [CrossRef] [PubMed]

15. Zhao, X.; Shao, C. Radiotherapy-Mediated Immunomodulation and Anti-Tumor Abscopal Effect Combining Immune Checkpoint Blockade. Cancers 2020, 12, 2762. [CrossRef]

16. MOLE, R.H. Whole Body Irradiation; Radiobiology or Medicine? Br. J. Radiol. 1953, 26, 234-241. [CrossRef]

17. Golden, E.B.; Demaria, S.; Schiff, P.B.; Chachoua, A.; Formenti, S.C. An Abscopal Response to Radiation and Ipilimumab in a Patient with Metastatic Non-Small Cell Lung Cancer. Cancer Immunol. Res. 2013, 1, 365-372. [CrossRef]

18. Liu, Y.; Dong, Y.; Kong, L.; Shi, F.; Zhu, H.; Yu, J. Abscopal Effect of Radiotherapy Combined with Immune Checkpoint Inhibitors. J. Hematol. Oncol. 2018, 11, 1-15. [CrossRef]

19. Chandra, R.A.; Wilhite, T.J.; Balboni, T.A.; Alexander, B.M.; Spektor, A.; Ott, P.A.; Ng, A.K.; Hodi, F.S.; Schoenfeld, J.D. A Systematic Evaluation of Abscopal Responses Following Radiotherapy in Patients with Metastatic Melanoma Treated with Ipilimumab. Oncoimmunology 2015, 4, 1-7. [CrossRef]

20. Mukhopadhyay, A.; Wright, J.; Shirley, S.; Canton, D.A.; Burkart, C.; Connolly, R.J.; Campbell, J.S.; Pierce, R.H. Characterization of Abscopal Effects of Intratumoral Electroporation-Mediated IL-12 Gene Therapy. Gene Ther. 2019, 26, 1-15. [CrossRef] [PubMed]

21. Iwai, T.; Oebisu, N.; Hoshi, M.; Orita, K.; Yamamoto, A.; Hamamoto, S.; Kageyama, K.; Nakamura, H. Promising Abscopal Effect of Combination Therapy with Thermal Tumour Ablation and Intratumoural OK-432 Injection in the Rat Osteosarcoma Model. Sci. Rep. 2020, 10, 9679. [CrossRef] [PubMed]

22. Abdo, J.; Cornell, D.L.; Mittal, S.K.; Agrawal, D.K. Immunotherapy plus Cryotherapy: Potential Augmented Abscopal Effect for Advanced Cancers. Front. Oncol. 2018, 8, 85. [CrossRef] [PubMed]

23. Tel, J.; Anguille, S.; Waterborg, C.E.J.; Smits, E.L.; Figdor, C.G.; de Vries, I.J.M. Tumoricidal Activity of Human Dendritic Cells. Trends Immunol. 2014, 35, 38-46. [CrossRef] [PubMed]

24. Gerlinger, M.; Rowan, A.J.; Horswell, S.; Larkin, J.; Endesfelder, D.; Gronroos, E.; Martinez, P.; Matthews, N.; Stewart, A.; Tarpey, P.; et al. Intratumor Heterogeneity and Branched Evolution Revealed by Multiregion Sequencing. N. Engl. J. Med. 2012, 366, 883-892. [CrossRef]

25. Mukherji, B. Immunology of Melanoma. Clin. Dermatol. 2013, 31, 156-165. [CrossRef]

26. Lee, Y.; Auh, S.L.; Wang, Y.; Burnette, B.; Wang, Y.; Meng, Y.; Beckett, M.; Sharma, R.; Chin, R.; Tu, T.; et al. Therapeutic Effects of Ablative Radiation on Local Tumor Require CD8 + T Cells: Changing Strategies for Cancer Treatment. Blood 2009, 114, 589-595. [CrossRef] [PubMed]

27. Demaria, S.; Ng, B.; Devitt, M.L.; Babb, J.S.; Kawashima, N.; Liebes, L.; Formenti, S.C. Ionizing Radiation Inhibition of Distant Untreated Tumors (Abscopal Effect) Is Immune Mediated. Int. J. Radiat. Oncol. Biol. Phys. 2004, 58, 862-870. [CrossRef]

28. Ribas, A.; Dummer, R.; Puzanov, I.; VanderWalde, A.; Andtbacka, R.H.I.; Michielin, O.; Olszanski, A.J.; Malvehy, J.; Cebon, J.; Fernandez, E.; et al. Oncolytic Virotherapy Promotes Intratumoral T Cell Infiltration and Improves Anti-PD-1 Immunotherapy. Cell 2017, 170, 1109-1119.e10. [CrossRef] [PubMed]

29. Marchini, A.; Daeffler, L.; Pozdeev, V.I.; Angelova, A.; Rommelaere, J. Immune Conversion of Tumor Microenvironment by Oncolytic Viruses: The Protoparvovirus H-1PV Case Study. Front. Immunol. 2019, 10, 1848. [CrossRef] [PubMed]

30. Capone, M.; Giannarelli, D.; Mallardo, D.; Madonna, G.; Festino, L.; Grimaldi, A.M.; Vanella, V.; Simeone, E.; Paone, M.; Palmieri, G.; et al. Baseline Neutrophil-to-Lymphocyte Ratio (NLR) and Derived NLR Could Predict Overall Survival in Patients with Advanced Melanoma Treated with Nivolumab. J. Immunother. Cancer 2018, 6, 1-7. [CrossRef]

31. Robert, C.; Thomas, L.; Bondarenko, I.; O’Day, S.; Weber, J.; Garbe, C.; Lebbe, C.; Baurain, J.-F.; Testori, A.; Grob, J.-J.; et al. Ipilimumab plus Dacarbazine for Previously Untreated Metastatic Melanoma. N. Engl. J. Med. 2011, 364, 2517-2526. [CrossRef] 
32. Schadendorf, D.; Hodi, F.S.; Robert, C.; Weber, J.S.; Margolin, K.; Hamid, O.; Patt, D.; Chen, T.T.; Berman, D.M.; Wolchok, J.D. Pooled Analysis of Long-Term Survival Data from Phase II and Phase III Trials of Ipilimumab in Unresectable or Metastatic Melanoma. J. Clin. Oncol. 2015, 33, 1889-1894. [CrossRef]

33. Grimaldi, A.M.; Simeone, E.; Giannarelli, D.; Muto, P.; Falivene, S.; Borzillo, V.; Giugliano, F.M.; Sandomenico, F.; Petrillo, A.; Curvietto, M.; et al. Abscopal Effects of Radiotherapy on Advanced Melanoma Patients Who Progressed after Ipilimumab Immunotherapy. Oncoimmunology 2014, 3, e28780. [CrossRef]

34. Liang, H.; Deng, L.; Chmura, S.; Burnette, B.; Liadis, N.; Darga, T.; Beckett, M.A.; Lingen, M.W.; Witt, M.; Weichselbaum, R.R.; et al. Radiation-Induced Equilibrium Is a Balance between Tumor Cell Proliferation and T Cell-Mediated Killing. J. Immunol. 2013, 190, 5874-5881. [CrossRef]

35. Park, S.S.; Dong, H.; Liu, X.; Harrington, S.M.; Krco, C.J.; Grams, M.P.; Mansfield, A.S.; Furutani, K.M.; Olivier, K.R.; Kwon, E.D. PD-1 Restrains Radiotherapy-Induced Abscopal Effect. Cancer Immunol. Res. 2015, 3, 610-619. [CrossRef] [PubMed]

36. Pilones, K.A.; Kawashima, N.; Yang, A.M.; Babb, J.S.; Formenti, S.C.; Demaria, S. Invariant Natural Killer T Cells Regulate Breast Cancer Response to Radiation and CTLA-4 Blockade. Clin. Cancer Res. 2009, 15, 597-606. [CrossRef] [PubMed]

37. Milano, M.T.; Katz, A.W.; Zhang, H.; Okunieff, P. Oligometastases Treated with Stereotactic Body Radiotherapy: Long-Term Follow-up of Prospective Study. Int. J. Radiat. Oncol. Biol. Phys. 2012, 83, 878-886. [CrossRef] [PubMed]

38. Salama, J.K.; Hasselle, M.D.; Chmura, S.J.; Malik, R.; Mehta, N.; Yenice, K.M.; Villaflor, V.M.; Stadler, W.M.; Hoffman, P.C.; Cohen, E.E.W.; et al. Stereotactic Body Radiotherapy for Multisite Extracranial Oligometastases: Final Report of a Dose Escalation Trial in Patients with 1 to 5 Sites of Metastatic Disease. Cancer 2012, 118, 2962-2970. [CrossRef]

39. Schreiber, R.D.; Old, L.J.; Smyth, M.J. Cancer Immunoediting: Integrating Immunity's Roles in Cancer Suppression and Promotion. Science 2011, 331, 1565-1570. [CrossRef]

40. Zhang, D.; Bi, J.; Liang, Q.; Wang, S.; Zhang, L.; Han, F.; Li, S.; Qiu, B.; Fan, X.; Chen, W.; et al. VCAM1 Promotes Tumor Cell Invasion and Metastasis by Inducing EMT and Transendothelial Migration in Colorectal Cancer. Front. Oncol. 2020, 10, 1066. [CrossRef]

41. Johnson, J.P. Cell Adhesion Molecules in the Development and Progression of Malignant Melanoma. Cancer Metastasis Rev. 1999, 18, 345-357. [CrossRef]

42. Reits, E.A.; Hodge, J.W.; Herberts, C.A.; Groothuis, T.A.; Chakraborty, M.; Wansley, E.K.; Camphausen, K.; Luiten, R.M.; De Ru, A.H.; Neijssen, J.; et al. Radiation Modulates the Peptide Repertoire, Enhances MHC Class I Expression, and Induces Successful Antitumor Immunotherapy. J. Exp. Med. 2006, 203, 1259-1271. [CrossRef] [PubMed]

43. Chakraborty, M.; Abrams, S.I.; Camphausen, K.; Liu, K.; Scott, T.; Coleman, C.N.; Hodge, J.W. Irradiation of Tumor Cells Up-Regulates Fas and Enhances CTL Lytic Activity and CTL Adoptive Immunotherapy. J. Immunol. 2003, 170, 6338-6347. [CrossRef] [PubMed]

44. Fuertes, M.B.; Kacha, A.K.; Kline, J.; Woo, S.R.; Kranz, D.M.; Murphy, K.M.; Gajewski, T.F. Host Type I IFN Signals Are Required for Antitumor CD8+ T Cell Responses through CD8 $\alpha+$ Dendritic Cells. J. Exp. Med. 2011, 208, 2005-2016. [CrossRef] [PubMed]

45. Grasso, C.S.; Tsoi, J.; Onyshchenko, M.; Abril-Rodriguez, G.; Ross-Macdonald, P.; Wind-Rotolo, M.; Champhekar, A.; Medina, E.; Torrejon, D.Y.; Shin, D.S.; et al. Conserved Interferon- $\gamma$ Signaling Drives Clinical Response to Immune Checkpoint Blockade Therapy in Melanoma. Cancer Cell 2020, 38, 500-515.e3. [CrossRef] [PubMed]

46. Zhou, J.; Wang, G.; Chen, Y.; Wang, H.; Hua, Y.; Cai, Z. Immunogenic Cell Death in Cancer Therapy: Present and Emerging Inducers. J. Cell. Mol. Med. 2019, 23, 4854-4865. [CrossRef] [PubMed]

47. Gardai, S.J.; McPhillips, K.A.; Frasch, S.C.; Janssen, W.J.; Starefeldt, A.; Murphy-Ullrich, J.E.; Bratton, D.L.; Oldenborg, P.A.; Michalak, M.; Henson, P.M. Cell-Surface Calreticulin Initiates Clearance of Viable or Apoptotic Cells through Trans-Activation of LRP on the Phagocyte. Cell 2005, 123, 321-334. [CrossRef]

48. Perregaux, D.G.; McNiff, P.; Laliberte, R.; Conklyn, M.; Gabel, C.A. ATP Acts as an Agonist to Promote Stimulus-Induced Secretion of IL-1 $\beta$ and IL-18 in Human Blood. J. Immunol. 2000, 165, 4615-4623. [CrossRef]

49. Vijay, K. Toll-like Receptors in Immunity and Inflammatory Diseases: Past, Present, and Future. Int. Immunopharmacol. 2018, 59, 391-412. [CrossRef] [PubMed]

50. Herrera, F.G.; Bourhis, J.; Coukos, G. Radiotherapy Combination Opportunities Leveraging Immunity for the next Oncology Practice. CA. Cancer J. Clin. 2017, 67, 65-85. [CrossRef]

51. Pedicord, V.A.; Montalvo, W.; Leiner, I.M.; Allison, J.P. Single Dose of Anti-CTLA-4 Enhances CD8+ T-Cell Memory Formation, Function, and Maintenance. Proc. Natl. Acad. Sci. USA 2011, 108, 266-271. [CrossRef]

52. Herbst, R.S.; Baas, P.; Kim, D.W.; Felip, E.; Pérez-Gracia, J.L.; Han, J.Y.; Molina, J.; Kim, J.H.; Arvis, C.D.; Ahn, M.J.; et al. Pembrolizumab versus Docetaxel for Previously Treated, PD-L1-Positive, Advanced Non-Small-Cell Lung Cancer (KEYNOTE010): A Randomised Controlled Trial. Lancet 2016, 387, 1540-1550. [CrossRef]

53. Long, G.V.; Larkin, J.; Ascierto, P.A.; Hodi, F.S.; Rutkowski, P.; Sileni, V.; Hassel, J.; Lebbe, C.; Pavlick, A.C.; Wagstaff, J.; et al Melanoma and Other Skin Tumours 1112PD PD-L1 Expression as a Biomarker for Nivolumab (NIVO) plus Ipilimumab (IPI) and NIVO Alone in Advanced Melanoma (MEL): A Pooled Analysis. Ann. Oncol. 2016, 27, 379-400. [CrossRef]

54. Deng, L.; Liang, H.; Burnette, B.; Beckett, M.; Darga, T.; Weichselbaum, R.R.; Fu, Y.X. Irradiation and Anti-PD-L1 Treatment Synergistically Promote Antitumor Immunity in Mice. J. Clin. Investig. 2014, 124, 687-695. [CrossRef] [PubMed]

55. Tsui, J.M.; Mihalcioiu, C.; Cury, F.L. Abscopal Effect in a Stage IV Melanoma Patient Who Progressed on Pembrolizumab. Cureus 2018, 10, e2238. [CrossRef] [PubMed] 
56. Tchanque-Fossuo, C.N.; Eisen, D.B. A Systematic Review on the Use of Cryotherapy versus Other Treatments for Basal Cell Carcinoma. Dermatol. Online J. 2018, 24. [CrossRef]

57. Zeng, Y.; Hu, C.; Shu, L.; Pan, Y.; Zhao, L.; Pu, X.; Wu, F. Clinical Treatment Options for Early-Stage and Advanced Conjunctival Melanoma. Surv. Ophthalmol. 2020, 66, 461-470. [CrossRef]

58. John, H.E.; Mahaffey, P.J. Laser Ablation and Cryotherapy of Melanoma Metastases. J. Surg. Oncol. 2014, 109, 296-300. [CrossRef]

59. Bala, M.M.; Riemsma, R.P.; Wolff, R.; Kleijnen, J. Cryotherapy for Liver Metastases. Cochrane Database Syst. Rev. 2013, CD009058. [CrossRef]

60. Slovak, R.; Ludwig, J.M.; Gettinger, S.N.; Herbst, R.S.; Kim, H.S. Immuno-Thermal Ablations-Boosting the Anticancer Immune Response. J. Immunother. Cancer 2017, 5, 1-15. [CrossRef] [PubMed]

61. Gazzaniga, S.; Bravo, A.; Goldszmid, S.R.; Maschi, F.; Martinelli, J.; Mordoh, J.; Wainstok, R. Inflammatory Changes after Cryosurgery-Induced Necrosis in Human Melanoma Xenografted in Nude Mice. J. Investig. Dermatol. 2001, 116, 664-671. [CrossRef]

62. Liu, Y.C.; Zou, X.B.; Chai, Y.F.; Yao, Y.M. Macrophage Polarization in Inflammatory Diseases. Int. J. Biol. Sci. 2014, 10, 520-529. [CrossRef] [PubMed]

63. Zhou, J.; Tang, Z.; Gao, S.; Li, C.; Feng, Y.; Zhou, X. Tumor-Associated Macrophages: Recent Insights and Therapies. Front. Oncol. 2020, 10, 188. [CrossRef]

64. Gu, Y.; Srimathveeravalli, G.; Cai, L.; Ueshima, E.; Maybody, M.; Yarmohammadi, H.; Zhu, Y.S.; Durack, J.C.; Solomon, S.B.; Coleman, J.A.; et al. Pirfenidone Inhibits Cryoablation Induced Local Macrophage Infiltration along with Its Associated TGFb1 Expression and Serum Cytokine Level in a Mouse Model. Cryobiology 2018, 82, 106-111. [CrossRef]

65. Takahashi, Y.; Izumi, Y.; Matsutani, N.; Dejima, H.; Nakayama, T.; Okamura, R.; Uehara, H.; Kawamura, M. Optimized Magnitude of Cryosurgery Facilitating Anti-Tumor Immunoreaction in a Mouse Model of Lewis Lung Cancer. Cancer Immunol. Immunother. 2016, 65, 973-982. [CrossRef] [PubMed]

66. Den Brok, M.H.M.G.M.; Sutmuller, R.P.M.; Nierkens, S.; Bennink, E.J.; Toonen, L.W.J.; Figdor, C.G.; Ruers, T.J.M.; Adema, G.J. Synergy between in Situ Cryoablation and TLR9 Stimulation Results in a Highly Effective in Vivo Dendritic Cell Vaccine. Cancer Res. 2006, 66, 7285-7292. [CrossRef] [PubMed]

67. Lacina, L.; Kodet, O.; Dvořánková, B.; Szabo, P.; Smetana, K. Ecology of Melanoma Cell. Histol. Histopathol. 2018, 33, $247-254$.

68. Dvorak, H.F. Tumors: Wounds That Do Not Heal-Redux. Cancer Immunol. Res. 2015, 3, 1-11. [CrossRef]

69. Jobe, N.P.; Živicová, V.; Mifková, A.; Rösel, D.; Dvořánková, B.; Kodet, O.; Strnad, H.; Kolář, M.; Šedo, A.; Smetana, K.; et al. Fibroblasts Potentiate Melanoma Cells in Vitro Invasiveness Induced by UV-Irradiated Keratinocytes. Histochem. Cell Biol. 2018, 149, 503-516. [CrossRef]

70. Čoma, M.; Fröhlichová, L.; Urban, L.; Zajícĕk, R.; Urban, T.; Szabo, P.; Novák, Š.; Fetissov, V.; Dvořánková, B.; Smetana, K.; et al. Molecular Changes Underlying Hypertrophic Scarring Following Burns Involve Specific Deregulations at Allwound Healing Stages (Inflammation, Proliferation and Maturation). Int. J. Mol. Sci. 2021, 22, 897. [CrossRef]

71. Ressler, J.M.; Karasek, M.; Koch, L.; Silmbrod, R.; Mangana, J.; Latifyan, S.; Aedo-Lopez, V.; Kehrer, H.; Weihsengruber, F.; Koelblinger, P.; et al. Real-Life Use of Talimogene Laherparepvec (T-VEC) in Melanoma Patients in Centers in Austria, Switzerland and Germany. J. Immunother. Cancer 2021, 9, e001701. [CrossRef] [PubMed]

72. Kepp, O.; Marabelle, A.; Zitvogel, L.; Kroemer, G. Oncolysis without Viruses-Inducing Systemic Anticancer Immune Responses with Local Therapies. Nat. Rev. Clin. Oncol. 2020, 17, 49-64. [CrossRef] [PubMed] 